\title{
Borrowed Halos: \\ Canadian Teachers as Voluntary Aid Detachment Nurses during the Great War ${ }^{1}$
}

\author{
Linda J. Quiney
}

In the early twentieth century, teaching and nursing both offered middle-class women viable career choices. ${ }^{2}$ There were other career opportunities open to unmarried, middle-class women, but few required the extensive specialized training demanded of nurses and teachers. In 1914 the Great War necessitated a realignment of the workplace and the suitable employment choices available to working women, as more than 600,000 Canadian men eventually departed overseas for active military service. Only the 3,141 qualified nurses recruited by the Canadian Army Medical Corps (CAMC) were officially required for military nursing service abroad in Canada's military hospitals. ${ }^{3}$ For their part, women teachers, unlike their male counterparts, were expected to remain in their classrooms for the duration of the war. Yet for some this "status quo" was not sufficient, and for a brief time, at least forty Canadian women teachers relinquished their identity as professional educators to assume the temporary role of a Voluntary Aid Detachment nurse, or VAD, many serving in British military

1 The author gratefully acknowledges the generous support for this research of the Hannah Institute for the History of Medicine through Associated Medical Services, Inc., Toronto; and the University of Ottawa, School of Graduate Studies.

2 Kathryn McPherson, Bedside Matters: The Transformation of Canadian Nursing, 1900-1990 (Toronto: Oxford University Press, 1996), esp. chap. 2. See also Alison Prentice, "Multiple Realities: The History of Women Teachers in Canada," in Feminism and Education: A Canadian Perspective, ed. Frieda Forman et al. (Toronto: O.I.S.E., 1990), and Geraldine Jonçich Clifford, "Daughters into Teachers: Educational and Demographic Influences on the Transformation of Teaching into Women's Work in America," in Women Who Taught: Perspectives on the History of Women and Teaching, ed. Alison Prentice and Marjorie R. Theobald (Toronto: University of Toronto Press, 1991), 115-35.

3 G. W. L. Nicholson, Canada's Nursing Sisters (Toronto: Samuel Stevens, Hakkert, 1975), 98; Meryn Stuart, "War and Peace: Professional Identities and Nurses' Training, 1914-1930," in Challenging Professions: Historical and Contemporary Perspectives on Women's Professional Work, ed. Elizabeth Smyth, Sandra Acker, Paula Bourne, and Alison Prentice (Toronto: University of Toronto Press, 1999), 173.

(C) Historical Studies in Education / Revue d'histoire de l'éducation 15, 1 (2003): 79-99 
hospitals in England, France, and other theatres of war. ${ }^{4}$ This article seeks to examine the history of these women, whose eagerness to "do their bit" for the war effort identified them temporarily with the role of both teacher and nurse. It considers the motivations behind their "active" war service, and the societal expectations that legitimized the temporary transformation from teacher to nurse during the crisis of war.

The war offered new, if only short-lived, employment opportunities for many women in the war industries, munitions factories, and business and service industries that opened up nontraditional positions left vacant when male workers enlisted for military service. ${ }^{5}$ In addition, an army of unpaid women volunteers converted their clubs and church groups into micro-war industries that produced food and medical supplies, and also collected unprecedented donations of goods and cash to support Red Cross initiatives. ${ }^{6}$ Led by the matrons of the privileged classes, who had the time, financial resources, and well-developed organizational skills, younger unmarried women also volunteered their time and energy, even when engaged full-time in waged employment or academic studies. ${ }^{7}$ Women undergraduates joined campus-based patriotic organizations, volunteering their time during summer vacations, and teachers were frequently involved in patriotic volunteer activities both in their schools and outside of working hours. ${ }^{8}$

All of these efforts stopped short of offering women direct involvement in the war overseas, with the exception of the Voluntary Aid Detachment program established by the Canadian

4 Note that reference to Canadian VADs includes those from Newfoundland unless otherwise indicated. Until April 1949, Newfoundland was a British colony.

5 Ceta Ramkhalawansingh, "Women During the Great War," in Women at Work: Ontario, 1850-1930, ed. Janet Acton et al. (Toronto: Canadian Women's Educational Press, 1974), 261-307.

6 Alison Prentice et al., eds., Canadian Women: A History (Toronto: Harcourt Brace \& Co., 1996), 230-34.

7 Donna Fallis, “World War I Knitting,” Alberta Museums Review (Fall 1984): 8-10; Desmond Morton and Cheryl Smith, "Fuel for the Home Fires: The Patriotic Fund, 19141918,” The Beaver 75:4 (Aug./Sept. 1995): 12-19; Gwen Szychter, “The War Work of Women in Rural British Columbia: 1914-1919,” British Columbia Historical News 27, 4 (Fall 1994): 5-9; Natalie M. Riegler, "Sphagnum Moss in World War I: The Making of Surgical Dressings by Volunteers in Toronto, Canada, 1917-1918," Canadian Bulletin of Medical History 6, 1 (1989): 27-43; Gale Denise Warren, "The Patriotic Association of the Women of Newfoundland,” Aspects 33, 2 (Summer 1998): 23-32.

8 Margaret Wrong, "The War Work of University Women at Home," The Varsity Magazine Supplement (1918): 133-34; Szychter, "The War Work of Women in Rural British Columbia," 8. 
Branch of the St. John Ambulance, based on an existing British VAD scheme for training a reserve of volunteer nurses. ${ }^{9}$ By 1915 , however, increasing casualties overseas led Canada's St. John Ambulance Association (SJAA) to redirect its program for VAD nurses towards actively assisting in the ever-expanding numbers of local military convalescent hospitals at home. By 1916, St. John was also transporting their VADs overseas to work in British military hospitals. Although Canada's VAD enrolment would never approach the more than 23,000 British VAD nurses of the Great War, the Canadian response was significant given the much smaller population base. ${ }^{10}$ At the close of 1917, St. John Ambulance could boast an enrolment of more than 1,800 Canadian VADs, with at least 500 overall having experienced "active service" overseas before the Armistice. ${ }^{11}$

Recruited from across Canada and Newfoundland, the VADs were predominantly Anglo-Protestant, middle-class, unmarried, and in their mid-twenties to early thirties. ${ }^{12}$ British scholarship traditionally situates the VADs within the upper middle-classes, and outside of the labour market. Recently, however, these conclusions have been challenged as an idealized image of the VAD promoted by wartime propaganda and post-war nostalgia. ${ }^{13}$ Many of Canada's VAD recruits were certainly familiar with waged employment; 194 of the 808 VADs identified are known to have held paid jobs prior to their VAD service. These were

9 The British plan for voluntary aid was approved by the War Office in 1909 as the Scheme for the Organisation of Voluntary Aid in England and Wales. The Canadian version was authorized in March 1914 by the Militia Council as The Organisation of Voluntary Medical Aid in Canada.

10 M. C. Urquhart, ed., Historical Statistics of Canada (Toronto: Macmillan, 1965), A1-A19. Census data record the population of Canada as 7,206,643 in 1911, and 8,787,949 in 1921. See also Anne Summers, Angels and Citizens: British Women as Military Nurses, 1854-1914 (London: Routledge \& Kegan Paul, 1988).

11 St. John Ambulance Brigade, Report of the Chief Commissioner for Brigade Overseas: 1 October 1915 to 31 December 1917 (Earl of Ranfurly, comp.), 35. A total of 1,789 women VADs in Canada, plus 51 from Newfoundland, were recorded to the end of December 1917. This does not include those who signed on independently with Devonshire House as British Red Cross VADs, or those who became VADs after December 31, 1917.

12 British Red Cross Society (BRCS), Museum \& Archives (M\&A), Personnel Card Indexes: Military Hospital Files/Record Cards.

13 The British scholarship includes: Summers, Angels and Citizens, esp. chap. 9, and Lyn Macdonald, The Roses of No Man's Land (London: Penguin, 1993 [c. 1980]). A 1916 survey of 200 British VAD nurses demonstrates that at least 25 per cent had experience in waged employment, including domestic and factory work. See Imperial War Museum (IWM), Women at Work Collection (BRCS 10.5/4), “Analysis of 200 Cases of Selected Members Taken at Random (28 Nov. 1916)”; also, Deborah Gorham, Vera Brittain: A Feminist Life (Toronto: University of Toronto Press, 2000), 101. 
primarily occupations considered suitable for middle-class women of the era, such as clerical work, banking, public service, and other white-collar occupations (see Table A). ${ }^{14}$

In the case of the teachers, however, their specialized training, and the higher academic achievement required for those who taught at the secondary level, were notable among those women who had opted for unpaid VAD service. The 40 teachers identified constituted a significant portion of the 194 women known to have been employed prior to their VAD service. Overall, qualified teachers comprised the second largest identifiable occupational group, after clerical workers, to serve as Canadian VAD nurses during the Great War. They traded salaried positions in both public and independent schools for unpaid VAD service in the British military hospitals, working under the direct supervision of military nurses and the authority of hospital matrons. Far removed from the schoolroom, the VAD teachers cleaned the wards, served meals, changed beds, and helped to bathe and feed sick and wounded men. When given the opportunity, they also helped the nurses to clean and dress often horrific and badly infected wounds, and when the need arose, could be assigned to assist the nurses in the operating theatres. Depending upon where they served and under whose direction, at home and overseas, the VADs were expected to perform tasks ranging from basic domestic service to those of night nurse in sole charge of a ward, and all manner of work in between.

Why these Canadian teachers chose to relinquish their salaried jobs for unpaid patriotic service as VADs speaks to the larger issues of gender and class that influenced all women VAD volunteers. The teachers were not alone in their desire to demonstrate their patriotic sympathies through their active voluntary participation in the war effort. Denied the opportunity to serve in a military capacity, Canadian women generally had ample opportunity to join the Red Cross or other organized women's voluntary war programs, packing boxes of comforts for the sick and wounded, or raising funds for ambulances and hospital ships through the sale of ribbons and badges. Women in their thousands contributed to these campaigns, but the St. John Ambulance Association offered a unique opportunity, as yet unrealized in 1914, of a much closer contact with the war through direct access to the

14 Linda J. Quiney, “Assistant Angels: Canadian Women as Voluntary Aid Detachment (VAD) Nurses during and after the Great War, 1914-1918” (Ph.D. diss., University of Ottawa, 2002), chap. 3. 
Table A: VADs Identified by Pre-War Waged Employment

\begin{tabular}{|c|c|c|c|c|c|c|}
\hline Occupation & $\begin{array}{l}\text { Maritimes \& } \\
\text { Newfoundland }\end{array}$ & Ontario & Toronto & Quebec & West & Total \\
\hline Arts & 2 & - & 2 & - & 2 & 6 \\
\hline Banking & 3 & 2 & 3 & - & 5 & 13 \\
\hline Clerical & 5 & 13 & 11 & 1 & 26 & 56 \\
\hline $\begin{array}{l}\text { Factory or } \\
\text { Domestic }\end{array}$ & 1 & 3 & 1 & - & 1 & 6 \\
\hline Government & - & 15 & 2 & - & 20 & 37 \\
\hline Librarian & 2 & - & - & - & 2 & 4 \\
\hline Nurse & 1 & 4 & - & 3 & 2 & 10 \\
\hline Professional & 1 & 2 & 1 & - & 1 & 5 \\
\hline $\begin{array}{l}\text { Sales and } \\
\text { Service }\end{array}$ & - & 2 & 1 & 1 & 7 & 11 \\
\hline Teacher & 3 & 6 & 4 & 1 & 26 & 40 \\
\hline $\begin{array}{l}\text { Telephone } \\
\text { Operator }\end{array}$ & - & 2 & 1 & - & 3 & 6 \\
\hline Total & 18 & 49 & 26 & 6 & 95 & 194 \\
\hline
\end{tabular}

Source: Canadian City Directories and Personal Documents of Individual VADs 
wounded soldier. Hazel Todd, organizer and Commandant of Ottawa's VAD detachment, reflected on the enthusiastic response of the women as an expression of their "patriotism and sympathy" with the war effort in general, and with the soldiers as the primary participants. In Todd's estimation, the VAD movement presented women with "an opportunity of allowing themselves, and their efforts, to be organized and coordinated efficiently, so the sick and wounded may derive the fullest possible benefit." 15

As the casualty lists lengthened and losses intensified their patriotic impulses, young women were increasingly drawn to VAD service as a means of achieving a more direct involvement with the conduct of the war. No other volunteer work offered women such direct access to the conflict abroad, and British scholarship has characterized women's VAD work as the equivalent of "soldiering” for men, being both voluntary and outside of their usual peacetime role. ${ }^{16}$ The heroic legacy of Florence Nightingale in the Crimea, glowing newspaper reports of British VAD work in hospitals overseas, and a wealth of visual and print propaganda promoting romantic images of feminine, white-veiled nurses proffering the "healing touch of a woman's hand," linked patriotism and gender, legitimizing the entry of casually trained volunteer nurses into the military hospitals abroad. ${ }^{17}$ For qualified women, military nursing offered a variation on their regular peacetime nursing work, and, as Meryn Stuart argues, their patriotism was further encouraged by new opportunities for travel and adventure with the CAMC nursing service. ${ }^{18}$ One veteran VAD recalled the abundance of propaganda posters proclaiming: "Your King and Country Need You!" which exhorted young men to fight, and young women to support their efforts; when her young brother enlisted with his classmates, she was determined to match his patriotism by volunteering to nurse

15 Ottawa City Archives (OCA), MG26, D83, St. John Ambulance Association, Records, 1910-1927, "Minutes, 24 Nov. 1914.” Hazel Todd helped initiate the Ottawa Woman's Detachment in November 1914; she was also noted for assisting prospective members with First Aid Instruction, and "drilling these girls in the practical work of bandaging, etc."

16 Janet Sledge Kobrin Watson, "Active Service: Gender, Class and British Representations of the Great War” (Ph.D. diss., Stanford, 1996), 133 and 160. See also, Sharon Ouditt, Fighting Forces, Writing Women: Identity and Ideology in the First World War (London/New York: Routledge, 1994), 32-34.

17 Maurice F. W. Doll, The Poster War: Allied Propaganda Art of the First World War (Edmonton: Alberta Community Development, 1993), 41, and Plates 3, 22, 23. See also The Times, 9 July 1915; The Times History of the War, Volume IV (London: The Times, 1915), 241-80, esp. 247-50.

18 Stuart, "War and Peace," 171. 
overseas. ${ }^{19}$ Unable to join their brothers, friends, and fiancés on the battlefield, young women lacking the qualifications of trained nurses saw VAD service as an unparalleled opportunity to support the "boys" overseas, and to demonstrate their own sense of patriotism through a unique form of "active service." More than half a century later, one veteran VAD declared: "Canadian men were going over, and if Canadian women got a chance to go, they should go and help!"”20

In the estimation of historian Janet Watson, wartime voluntary service was an almost innate response for young middle and upperclass women of British origin. Watson concludes that for these women in particular, who had been taught "the same language of patriotism, honour, sacrifice and empire as their brothers at home and, more recently at school, the hospital became their displaced trench." ${ }^{21}$ Canadian women of British origin were no less affected by the rhetoric of patriotism, and the more personal emotions of anxiety or loss experienced for their brothers and fiancés who had bravely enlisted for military service on distant shores.

The teachers were as vulnerable to these influences as any Canadian women. Although it is impossible to ascertain exactly how many Canadian teachers trained as VADs and subsequently volunteered for overseas service, their sizeable representation among those selected for this privilege indicates their particular suitability for the work. Intelligent, educated, and industrious, the teachers were trained, working women who had already demonstrated their abilities to learn new skills, their organizational capabilities in the classroom, and their willingness to operate within the structured supervisory hierarchy of the education system. With their proven employment record, women teachers constituted ideal candidates to represent the Canadian St. John Ambulance VAD service overseas.

At the outset of the war, however, St. John initially envisaged only a subsidiary role for VAD nurses, as a "supplement to the Militia Medical Service" in the event of invasion on home soil. ${ }^{22}$ Men had been expected to take the larger role as VAD ambulance

19 Silva Basmajian, producer, And We Knew How to Dance (National Film Board, 1993).

20 National Archives of Canada (NAC), A1 9903-0008, The Great War and Canadian Society: Opportunities for Youth Project, "Jean Marita Sears Interview," 18 June 1974; Daphne Read, ed., The Great War and Canadian Society: An Oral History (Toronto: New Hogtown Press, 1978), 98.

21 Watson, “Active Service,” 23.

22 The Organisation of Voluntary Medical Aid in Canada (1914), 3. 
attendants and stretcher bearers, and it was anticipated they would outnumber the female VAD nursing members by two to one in each detachment. ${ }^{23}$ Prior to 1914 fewer than 50 women had enrolled as members of the St. John Ambulance Brigade Nursing Divisions, created as an adjunct to the local Ambulance Divisions, less than 10 per cent overall. ${ }^{24}$ With the declaration of war, however, those men who were already active Brigade members, and most other potential male candidates, were quickly recruited for the military or absorbed into the war industries, and new recruits were not forthcoming. ${ }^{25}$

All potential VAD members, whether male or female, were required to pass the St. John Ambulance course in First Aid in order to qualify, but women candidates were required to undertake a second course in Home Nursing. Each course consisted of weekly, two-hour lecture and demonstration sessions conducted over six weeks, plus an examination under the supervision of a physician, which was usually practical rather than written. ${ }^{26}$ The larger part of VAD nurses' training, however, like that of the qualified military nurses who supervised them, was in reality acquired through practical experience on the hospital wards. Dr. Charles Copp, the director of the St. John Ambulance VAD program in Canada, confidently asserted that the VAD nursing recruits were drawn primarily "from the best homes." A fee of approximately $\$ 2$ per course, for materials and text, helped to ensure that the applicants met this criterion. A further stipulation that only women aged 21 to 48 years were eligible to apply also determined the maturity of the candidates. ${ }^{27}$ Trained graduate nurses were not accepted for VAD service, in order to reserve their services for regular nursing duties, although retired nurses were

23 Ibid., 5.

24 Annual Report for 1913 of the St. John Ambulance Brigade Overseas: Within the Dominion of Canada (G. R. N. Collins Capt., comp.), 13.

25 Archives of Ontario, MU6814, St. John Ambulance Association Administrative Records, "Report of the Ontario Provincial, Canadian Branch, St. John Ambulance Association (1915),” 2. The Secretary for the Ottawa area noted with displeasure that few men had enrolled in the First Aid courses for VAD ambulance members.

26 Annual Report for 1913, 23.

27 British regulations also stipulated that VAD nurses eligible for service outside of Britain be from 23 to 38 years of age. See Joint Women's VAD Department, Terms of Service (15 Mar. 1917), 2. 
encouraged to assist St. John Ambulance with VAD training and organization. ${ }^{28}$

The Nursing Sisters of the CAMC began their overseas service in Canadian military hospitals during the first months of the war. It was not until March 1915, however, that the VADs were permitted to assume any regular hospital duties, initially in the Canadian military convalescent hospitals established in Montreal and several other urban centres. It was September 1916 before the first "official" contingent of sixty Canadian VADs bound for overseas service finally embarked for England, where they were welcomed only in the British military hospitals. ${ }^{29}$ Throughout the war the CAMC hierarchy remained adamantly opposed to permitting civilian volunteers, and particularly women volunteers as VAD nurses, to work in their hospitals overseas. The fear was that both military discipline, and the status of the nursing service, would be undermined by the presence of these unqualified nursing volunteers. ${ }^{30}$ The greater number of Canada's VADs remained at home to serve as nursing assistants in one of the many military convalescent facilities established across Canada. ${ }^{31}$ However, approximately 500 Canadian VADs eventually found a post in one of the British hospitals, some having ventured overseas on their own initiative. ${ }^{32}$ In practice, overseas VAD work was nominally voluntary, since only those who were posted to British military hospitals abroad received compensation for their basic expenses of

28 "Report of the Ontario Provincial, Canadian Branch, St. John Ambulance Association (1915)"; G. W. L. Nicholson, The White Cross in Canada: A History of St. John Ambulance (Montreal: Harvest House, 1967), 56; Annual Report for 1913, 22; Dr. Charles Copp, “The St. John’s Ambulance Brigade,” Canadian Nurse 14:7 (July 1918): 1163-64. 29 In September 1914, 101 Canadian Nursing Sisters embarked as the First Contingent for overseas service with the CAMC. See Nicholson, Canada's Nursing Sisters, 53. Montreal VADs were the first to serve in local convalescent hospitals. See Mrs. Henderson, "VAD Work in Montreal," Canadian Nurse, 14:8 (April 1918): 1245-46.

30 Henderson, "VAD Work in Montreal,” 1246; Linda J. Quiney, “'Sharing the Halo': Social and Professional Tensions in the Work of World War I Canadian Volunteer Nurses," Journal of the Canadian Historical Association 9 (1998): 111-12. The few Canadians who were eventually posted as VADs to CAMC hospitals, about 15 women in all, were assigned non-nursing duties.

31 Annmarie Adams, "Borrowed Buildings: Canada’s Temporary Hospitals during World War I," Canadian Bulletin of Medical History 16:1 (1999): 25-48.

32 At least 100 women made a direct application to the British Red Cross VAD organization in London, many later joining the Canadian Imperial VAD organization established in 1918. See Reports by the Joint War Committee and the Joint War Finance Committee of the British Red Cross Society and the Order of St. John of Jerusalem in England on: Voluntary Aid Rendered to the Sick and Wounded at Home and Abroad and to British Prisoners of War, 1914-1919 (1921), 196. 
uniform, laundry, and travel, and had their food and lodging guaranteed. ${ }^{33}$ Although this stipend did not replace lost salary, the teachers and countless other Canadian women nevertheless eagerly sought VAD service abroad, and St. John Ambulance kept waiting lists for overseas VAD postings throughout the war.

As in the case of the military nurses, however, not all of the Canadian VADs were solely motivated by a lofty patriotic idealism. Among them was Agnes Wilson, a teacher from Edmonton, who freely admitted that her attraction to VAD work was far more practical and opportunistic. She readily acknowledged that "I didn't like teaching as a matter of fact!" and VAD service provided an acceptable excuse for leaving her job. ${ }^{34}$ Agnes Wilson was one of seven women among the first class of thirty-eight students to graduate from the University of Alberta in 1912. The daughter of a pioneer Edmonton merchant and banker, Agnes entered the University of Alberta in 1908. The majority of her fellow students had come either directly out of grade 11 or 12 , or were returning to their studies after several years in the field as ministers and missionaries, few among them having taken matriculation examinations. ${ }^{35}$ Following graduation Agnes helped support the family finances with her teacher's salary, until her selection for overseas VAD service in 1918 offered a legitimate opportunity to leave the classroom behind without regret. ${ }^{36}$ She returned home in 1919 after a year of nursing in the British military hospitals in London, determined not to resume her teaching career. Instead, Agnes took a job with the university as secretary to the Dean of Arts and Sciences, working half-days while she attended a secretarial course in order to learn typing and shorthand. She

33 The VADs in British military hospitals were paid $£ 20$ per annum for the first six months, a stipend gradually raised to a maximum of $£ 30$ per annum, with a uniform allowance of $£ 4$ per annum. This was paid by the British government. St. John Ambulance and the Red Cross offered only "reasonable expenses" from debarkation in London, and necessary transportation, but there is no evidence of payment for VADs who remained in Canada. See Copp, “The St. John's Ambulance Brigade,” 1165. British wages at the time were $£ 30$ for a cook, $£ 25$ for a parlour maid, and $£ 14$ for a housemaid. See Ouditt, Fighting Forces, Writing Women, 15.

34 Public Archives of Alberta (PAA), MG73.72, "Agnes Wilson (Teviotdale) Interview,” 19 Jan. 1973.

35 Laurie Mook, "Women at University: The Early Years," Contents 44:1 (Winter 1996): 9. Wilson's father had uneven success in his business ventures, and when he retired in 1914, at age 70, the children took on the support of the family. Also see Agnes K. Teviotdale, Vast Prospects and Splendid Songs: Harry Wilson, Strathcona Pioneer of 1892 (Edmonton: Private Publication, 1972), 28.

36 Teviotdale, Vast Prospects and Splendid Songs, 28. 
continued this job until she married the university Registrar a few years later. ${ }^{37}$

Agnes Wilson's experience illustrates some common elements among the VAD teachers, including several who held university qualifications in addition to Normal School training. University accreditation was not uncommon among Canadian VADs generally, although it was by no means the standard, but served more as an indicator of the middle-class representation of Canadian VAD service. At least 35 of the more than 808 Canadian VADs identified are known to have achieved a college or university degree, and of these women, at least eight were employed as teachers for some time either before or after the war. ${ }^{38}$ This group included Marion Walwyn, the daughter of a United Church minister, who had graduated from the University of Toronto with an Arts degree in 1913 prior to entering the Regina Normal School. Agnes Wilson and Marion Walwyn, like countless other Canadian women in the early twentieth century, used their teaching qualifications as the stepping stone to a second career. Of the forty VADs who are known to have put aside their teaching careers for war service, only twenty-one returned to their jobs. ${ }^{39}$ Dissatisfaction with the work was only one of the numerous factors that contributed to this outcome, including marriage, and the death of one teacher from St. John's. Yet for some of these women teachers, VAD service appears to have contributed directly to their post-war choices for employment or further education, serving as a catalyst for change. In 1917, Marion Walwyn left her teaching position in Regina for a year of overseas VAD service in a British military hospital. Instead of returning home after her VAD assignment had concluded, Marion transferred to the Canadian YMCA in London as a volunteer, helping to organize activities for Canadian servicemen on leave. At the end of the war, Marion's volunteer experience provided the opportunity for a new, paid position as a tour guide for a Canadian travel company based in London. As a result, she permanently relinquished her teaching career, and by the 1940s had become a company director for her

37 “Agnes Wilson (Teviotdale) Interview”; Mook, “Women at University,” 9-10; BRCS, M\&A, Personnel Card Indexes.

38 An estimated 2,000 Canadian women served as VADs during the Great War. See Quiney, “Assistant Angels,” Appendix 2.

39 Ibid., 32, and Appendix 2. 
travel firm in Toronto. ${ }^{40}$ As with Agnes Wilson, wartime VAD service presented Marion Walwyn with the opportunity for a career change, reflecting to some extent the general sense of "restlessness" commonly experienced by the returning servicemen and military nurses in the post-war era. ${ }^{41}$

Many other well-educated veteran VAD teachers, nevertheless, returned to their classrooms following the war, including Elizabeth Kilpatrick, who was 34 when she concluded her year of VAD service in a British military hospital in Newcastle. Scottish by birth, Elizabeth had emigrated to Canada with her family as a young child. She returned to England to obtain her teaching certification after graduating from the University of Toronto in 1908, then subsequently took up a post in Toronto at St Margaret's College for girls. For nearly a year prior to her selection for overseas VAD service in 1918, Elizabeth had volunteered part-time for VAD work in a Toronto military convalescent hospital. The tradition of service was well established in Elizabeth's family; her father was a professor of divinity at Knox College in Toronto, her brother an army chaplain and later principal of a Toronto theological college, and her sister had been a missionary in India before settling into a teaching career. Not affected by a post-war need for change, Elizabeth also returned to Toronto and entered a new position at Branksome Hall, teaching English there until her retirement 25 years later. ${ }^{42}$

Frequently, the veteran VAD teachers returned to the classroom for a few years following their war service, then disappeared from the records. Often this was due to marriage, as with Margaret Carlyle, the daughter of a Toronto physician. Margaret had graduated from the University of Toronto in 1914 before qualifying as a teacher. Following eight months of VAD service in England, she returned to her teaching position at the Denison School in Toronto in the spring of 1919, but as of 1921 there is no further record of Margaret's career. ${ }^{43}$ Bessie Hall, a veteran Halifax VAD, returned briefly to the classroom after the

\footnotetext{
40 University of Toronto Archives (UTA), A73-0026/494 (68), Graduate Records, "Frances Marion Walwyn File"; BRCS, M\&A, Personnel Card Indexes.

41 Prentice et al., eds., Canadian Women, 244. This was a common experience of returning VADs.

42 UTA, A73-0026/201 (39), Graduate Records, "Elizabeth Kilpatrick File”; BRCS, M\&A, Personnel Card Indexes.

43 BRCS, M\&A, Personnel Card Indexes; G. Oswald Smith, University of Toronto Roll of Service, 1914-1918 (Toronto: University of Toronto Press, 1921); Toronto City Directory 1919 and 1921.
} 
war in order to finance her graduate work. She then followed a well-trodden path of early-twentieth-century women teachers who used their teacher's salary to finance their higher education, and moved on to a new career in social work. Bessie had initially supported her undergraduate studies at Dalhousie University with part-time teaching at the Halifax School for the Blind, graduating with "Distinction" in 1916. She then returned to full-time teaching until entering VAD service in a Halifax hospital in the fall of 1918, hoping for the opportunity to go overseas as a VAD. The Armistice ended any chance of a posting abroad, but Bessie remained in VAD service at a local military hospital through the flu epidemic and into the spring of 1919. Following a year of post-war teaching in Halifax, Bessie then moved to the University of Toronto, completed an M.A. in 1921, and subsequently exchanged her teacher's credentials for those of a social worker following a Ph.D. at Bryn Mawr. ${ }^{44}$

For many of these teachers, the decisions regarding career or marriage appear to have been directly influenced by their wartime VAD service at home or abroad. For some, their war service enhanced their self-confidence, promoting independent decisions regarding their future education or career. The majority of those teachers who saw "active” VAD service overseas remained on duty for an average of twelve months, or the duration of two VAD contract periods. In a few exceptions, however, some teachers opted for a longer term of service ranging from eighteen months to three years. ${ }^{45}$ At least five of the VAD teachers who remained in Canada, including Bessie Hall, served full-time as VAD nurses in military convalescent hospitals in their local communities. Those women who subsequently returned to the classroom following VAD service appear to have encountered few problems in re-establishing their careers. Some were reclaiming teaching posts traditionally held by women teachers at the elementary level, or in independent girls' schools, positions usually not open to returning male veterans. At this time however it was not uncommon for veteran VADs overall to benefit from established gender expectations when returning to the workplace. In the public service, the banks, and some private sector businesses, certain

44 Public Archives of Nova Scotia (PANS), MG1, Vol. 661, No. 8, McGregor-Miller Collection, "Bessie Hall Letters, 1913-1919"; Margaret Conrad, Toni Laidlaw, and Donna Smyth, eds., No Place Like Home: Diaries and Letters of Nova Scotia Women 1771-1938 (Halifax: Formac, 1988), 243-45 and 260.

45 BRCS, M\&A, Personnel Card Indexes. 
categories of jobs were often designated as suitable for women only, despite the thousands of men returning to the workforce after the war. ${ }^{46}$

Whatever their post-war career choices, however, the teachers who opted for VAD nursing as a form of patriotic war service had willingly put aside their own professional identity during the war to assume a completely different occupational role as volunteer nurses. Some had volunteered for VAD work part-time, outside of their regular paid working hours, as Elizabeth Kilpatrick had done for several months before she relinquished her teaching job to accept an overseas VAD posting. Unlike men, single working women were not expected to put aside their usual livelihood in order to demonstrate their patriotic duty; this was the exception rather than the norm. Although men had few options other than to fulfil the societal expectations for them to perform war service in uniform, a wide range of acceptable volunteer activities were available to women. Though they did not risk the kind of stigma incurred by civilian men through, for example, the "white-feather" campaigns, women still found it necessary to demonstrate an active patriotism through some form of voluntary war service. Yet for most, their patriotic service was easily reconcilable with waged employment or the demands of home and family, through the Red Cross and the many other patriotic women's organisations. ${ }^{47}$

There are no absolute answers to questions of why such a sizeable representation of women teachers so eagerly exchanged salary and job security for unpaid war service as a lowly VAD, in the unfamiliar and highly specialized world of hospital nursing. Propaganda campaigns, personal job dissatisfaction, and the adventure of new experiences overseas can all be cited as powerful influences. The teachers may also have regarded VAD service as work not unrelated to their own job description or professional identity as educators. As volunteer nurses, teachers substituted the

46 Amber Lloydlangston, "From Expendable to Indispensable? Women in Science in the Department of Agriculture During the First World War" (unpublished paper presented at the Canadian Historical Association Annual Conference, Ottawa, 1998), 14; Graham Lowe, "Women, Work and the Office: The Feminisation of Clerical Occupations in Canada, 1901-1931,” in Rethinking Canada: The Promise of Women's History, ed. Veronica Strong-Boag and A. C. Fellman (Toronto: Copp Clark Pitman, 1997), 253-70. 47 British women initiated the "white feather" as a symbol of cowardice for men not in uniform. Social pressure was used to ensure women took part in patriotic activities. See Nicolletta Gullace, "White Feathers and Wounded Men: Female Patriotism and Memory of the Great War,” Journal of British Studies 36 (Apr. 1997): 178-206. The necessity for women to be seen actively supporting the war, even at the local level, is discussed in Szychter, "The War Work of Women in Rural British Columbia,” 5-9. 
role of "nurturer" in the classroom for that of "care-giver" on the hospital wards, both tasks being recognized as acceptable forms of "women's work" outside the home. ${ }^{48}$ Their choice of VAD nursing as a patriotic endeavour was further reinforced by the rhetoric of wartime hospital discourse and the common social parlance of the era, which characterized the soldiers overseas as "the boys." The diaries and letters of the Canadian VADs and military nurses are replete with these allusions, equating hospital-ward camaraderie with the school-yard antics of lively children. As one VAD wrote from her hospital in England: "The boys are dears...And the pranks they are up to! The place is in an uproar half the time."49

For women teachers, therefore, the transposition of their identity from that of nurturer to nurse during the war was an acceptable response within the gendered dictates of women's patriotic service. From the perspective of the teachers, and VADs in general, VAD nursing offered women a unique incentive to make a dynamic and direct contribution to the war effort clothed in the uniform of a volunteer nurse. For a career nurse, the uniform was a powerful signifier of her specialized occupational role, and designated her pride both in affiliation with a particular training school and the nursing community overall. ${ }^{50}$ Canadian nurses were especially eager to earn the unique wartime distinction of wearing the uniform of a CAMC Nursing Sister, with its military insignia designating her rank as a Lieutenant. During the war the nursing associations complained that too few of their members were able to qualify for this privilege. ${ }^{51}$ The uniform of the St. John Ambulance VAD closely approximated that of the qualified military nurse, consisting of a grey work dress hemmed no less than eight inches from the floor, with starched white collar and cuffs, and a long, white-bibbed apron, adorned with the armband insignia of the SJAA. A severely styled grey dress uniform, plus a selection of hats and a heavy greatcoat for outerwear, completed the VAD ensemble. The ultimate glory however was the VADs' white kerchief, or "veil," the headpiece worn on duty, which

48 As noted by Clifford in "Daughters into Teachers," 117-18, the perception of school teaching as an extension of the maternal role outside the home enabled women to enter teaching as a paid occupation.

49 Buddig Annie Wynne-Roberts, "Extracts from Letters," in Letters from the Front: Being a Record of the Part Played by Officers of the Bank in the Great War, 1914-1919, Vol. 2, ed. Charles Lyon Foster (Toronto/Montreal: Southam, 1920), 161.

50 McPherson, Bedside Matters, 37-38, and 43.

51 Jean Gunn, "The Services of Canadian Nurses and Voluntary Aids During the War," Canadian Nurse 15, 9 (Sept. 1919): 1975. 
seemed to compliment all women, framing the face and endowing them with an aura of "saintly" femininity. Most VADs expressed their pleasure in the new experience of wearing the uniform, although some were dismayed by its asexual qualities. Bessie Hall was almost breathless with excitement when she was first "fitted like the lilies of the field" in her VAD uniform, and was doubly pleased to find it encouraged special discounts in the shops and cafés of Halifax. ${ }^{52}$ Few teachers outside of the parochial schools could boast a specialized uniform, and during the war the teachers, as with the VADs overall, considered themselves to be particularly allied to their brothers and fiancés in uniform.

In addition to the newly acquired benefit of the uniform, women teachers also had the advantage of their previous experience within the largely masculine hierarchy of the public school system. ${ }^{53}$ This may have allowed them to adapt more easily than other VADs to their subordinate role as volunteer nurse, the lowest rank in the strict female hierarchy of the British military nursing organisation. Overall, the Canadian teachers appear to have been well received as VADs, encountering few problems with the trained nursing establishment, unlike some other Canadian VADs who expressed difficulty in submitting to the authority of their nursing supervisors. ${ }^{54}$ Working on a voluntary basis, VADs had no fear of lost wages or job security attached to their performance review, just the pride of work well done. The demand for their services in British hospitals generally ensured that only the most serious misdemeanour would result in dismissal, but none of the identified Canadian teachers suffered this fate. Moreover, teaching and nursing both had equal social value as suitable "women's work" in the war era, an issue that was of greater concern to Canadian nursing leaders at the time with regard to their own professional aspirations. ${ }^{55}$ From the teachers' perspective, however, the association of soldiering with VAD nursing enhanced its attraction as a wartime activity, permitting their direct and active involvement in patriotic war service without challenging their virtue, femininity, or status as teachers.

52 PANS, McGregor-Miller Collection, “Bessie Hall Letters,” 2 Oct. 1918.

53 Alison Prentice, “The Feminisation of Teaching," in The Neglected Minority: Essays in Canadian Women's History, ed. Susan Mann Trofimenkoff and Alison Prentice (Toronto: McClelland \& Stewart, 1977), 49-65.

54 BRCS, M\&A, Personnel Card Indexes. The supervising hospital matrons recorded comments regarding the performance and character of the VADs on their cards, but the BRCS does not permit the publication of this data.

55 Clifford, “Daughters into Teachers,” 117-18. 
Apart from those teachers who left their established waged positions during the war for VAD work, a sizeable number of veteran VADs were also found to have opted for a teaching career in the post-war years. At least 28 veterans of wartime VAD service are known to have entered the teaching profession between 1920 and $1925 .^{56}$ The individual motivations behind these post-war career choices are unknown, nor can the possible influence of their VAD experience be accurately measured. One future teacher, Shirley Gordon, was still an undergraduate at the University of Toronto when she became a VAD in 1918. She later recounted her experiences, noting that VAD service was popular as the choice of voluntary war work among the women undergraduates. ${ }^{57}$ The University of Toronto undergraduate newspaper, The Varsity, reveals that women students were actively recruited on campus by the St. John Ambulance under the authority of the Red Cross, which was already engaged in wartime fund-raising and other campus-based patriotic activities. ${ }^{58}$

As a result of this program Shirley Gordon served as a VAD at the Davisville Military Convalescent Hospital in Toronto during the summer and fall of 1918, two years prior to graduating from the University of Toronto and proceeding on to Normal School. Gordon had chosen VAD work as her war service, because "everybody worked at something, if you were at the University you'd work during your holidays...but we were all needed!"59 At the Davisville Hospital, which specialized in reconstructive orthopaedic surgery, Gordon's initial duties involved little more than domestic service, such as making beds and cleaning the wards. As she gained the confidence of her supervisors, she was promoted to the Diet Kitchen to help to prepare special meals for the patients, and eventually she rose to the highest level of VAD service at Davisville, assisting the nurses with the surgical dressings. This coveted task involved handing supplies to the nurses, wringing out compresses, and sometimes putting on the "top," or finishing,

56 Data were taken from city directories across Canada and Newfoundland, and the personnel records of individual VADs. See Quiney, “Assistant Angels,” 29.

57 NAC, A1 9903-0015, The Great War and Canadian Society Project, "Shirley Gordon Interview,” 18 July 1974. Note that Mrs. Gordon’s maiden name is unknown.

58 The Varsity regularly reported on the numerous campus-based activities related to the war effort, including "Appeal for Workers for the Hospital Supply Association," The Varsity, 5 Feb. 1917, 1; and "Report of Patriotic Work Done by Women," The Varsity, 14 Mar. 1917, 1.

59 NAC, A1 9903-0015, The Great War and Canadian Society Project, "Shirley Gordon Interview,” 18 July 1974. 
bandages. These duties were similar to those assigned to beginning nursing students, designated as "probationers" in the teaching hospitals. $^{60}$

Shirley Gordon also recalled the hospital's strict rules regarding the VAD uniform, and having her hemline measured by the Matron to ensure it was the regulation eight inches from the floor. She described the rigorous military organization of the Davisville hospital, where all of the CAMC nurses were ranked as Lieutenant, and the VADs worked eight-hour shifts under the charge of a supervising military nurse. Gordon's supervisor was pleasant and friendly, but not all relations between the VADs and military nurses were as cordial. In Gordon's view, some of the nurses were understandably "resentful," fearing that the VADs were both a threat to their job security, and might undermine the status and respect the graduate nurses had worked hard to achieve since the Nightingale era. ${ }^{61}$ At the time however this attitude surprised Shirley Gordon and other VADs like her who were destined for a teacher's diploma. In the majority, the VADs regarded volunteer nursing as a wartime phenomenon, solely an expression of patriotic service, and most were initially unaware of the challenges they presented to the nursing community.

By late 1920 when the VAD program was officially demobilized, most of the VADs had already completed their war service and settled back into civilian life. The VADs received little public acknowledgement of their voluntary wartime efforts beyond the regulation military service medals received from the British War Office for service overseas; there was no official recognition from Canada for those who served in the hospitals at home. ${ }^{62}$ In one remarkable instance, however, the gratitude of a community resulted in a permanent public memorial for a teacher from St. John's, Newfoundland. Born and raised in St. John's, Ethel Dickenson was 16 when she passed the matriculation examinations at the Methodist College in 1896, before moving to Chicago to earn a teaching certificate. ${ }^{3}$ Dickenson returned home to teach clerical

\footnotetext{
60 Ibid.

61 Ibid.

62 Canadian VADs who served abroad in British military hospitals for more than six months received the British War Medal. Those who served in war zones received Victory \& General Service Medals. Others who served abroad in non-military hospitals or Canadian hospitals were given the St. John Ambulance War Service Badge. See St. John Ambulance Association, First Aid Bulletin, Dec. 1923, 15; and Nov. 1920, 7.

63 Ethel's name is variously recorded as "Dickinson” or "Dickenson," but the latter is inscribed on the memorial.
} 
skills at the college, until she entered the domestic science program at Macdonald College in Guelph in 1912. By 1914 Ethel was teaching at the interdenominational Domestic Science School in St. John's, but left this work in 1915 to visit her aunt in England. She remained there to pursue VAD service in the privately funded Lady Roberts' Convalescent Hospital in Ascot, outside of London, along with several friends from St. John's. ${ }^{64}$ In addition to this work, Ethel also volunteered part-time as a VAD at the Wandsworth Military Hospital in London, where many of the Newfoundland Regiment were sent to recover following the illfated battle of Beaumont Hamel on July 1, 1916. ${ }^{65}$ The heavy workload put a strain on Ethel's health, and she returned home in August 1918 for a rest, then resumed teaching in September. On October 1, returning sailors brought the Spanish Flu epidemic to St. John's, and Dickenson quickly reverted to her VAD role, to assist in one of the many emergency hospitals that were hastily organized with the rampant spread of the disease. Within three weeks, however, Dickenson herself succumbed to the infection and died October 26, $1918 .^{66}$

In an unprecedented gesture, the people of St. John's rallied to commemorate Dickenson's sacrifice, and by extension the efforts of all nurses, qualified or volunteer, who had served Newfoundland in the cause of the war and the epidemic. Overall, an estimated 60 Newfoundland women had served as VADs at home and overseas during the war. A public subscription raised $\$ 4,000$ to fund a 26foot granite monument in the form of a Celtic Cross, which was unveiled in central St. John's two years to the day after Dickenson's death. ${ }^{67}$ Apart from the military funerals for VADs who had died "on service" in the British hospitals overseas, Canada's VADs received no other public gesture of appreciation for their services from the nation. ${ }^{68}$

64 Bert Riggs, “What’s All the Fuss About Ethel Dickenson?” The Gazette [St. John’s], 6 July 1995.

65 Pamela Horwood, "Ethel Dickenson," in Remarkable Women of Newfoundland and Labrador, ed. St. John's Local Council of Women (St. John's: Valhalla Press, 1976), 17. During the Battle of the Somme, 310 of the Newfoundland Regiment died at Beaumont Hamel on 1 July 1916, out of approximately 500 men.

66 Riggs, "What's All the Fuss About Ethel Dickenson?”

67 Anon., "Unveiling the Dickenson Monument," The Newfoundland Quarterly (Christmas 1920), 8-9; J. R. Smallwood, ed., Encyclopedia of Newfoundland and Labrador, Vol. 1 (St. John's: Newfoundland Book Publishing, 1981), 621-22.

68 At least six Canadian VADs died "on service” from illness or infection. 
With little fanfare after the war, Canadian VADs resumed their former lives as private citizens and soon disappeared from the public consciousness. Yet the teachers, along with the estimated 2,000 other Canadian women who had donned the distinctive VAD uniforms in order to "do their bit" in hospitals at home and abroad during the war, had expected little more than the honour and privilege of serving their country. Their patriotic service had not derived from the "natural and divine instinct of nursing," as the inclination for VAD service was later characterized by one St. John Ambulance administrator. ${ }^{69}$ Nor had the teachers relinquished their salaried jobs in order to pursue a frustrated ambition for a nursing career, hoping to circumvent the three-year hospital training program and enter paid nursing work after the war. These women had already made their choices for education and a career that could provide them with a measure of economic independence, a distinct achievement for women of their era.

As trained and educated women, teachers were ideal candidates for wartime VAD service. Gender and class served to compensate for their lack of the specialized skills and experience of the qualified nurse. Moreover, as teaching professionals, their academic ability, learning capacity, and educational self-discipline guaranteed their aptitude for mastering unfamiliar new tasks and responding to supervision. As well-bred and intelligent women, teachers were considered to be as adequate to the role of nursing as they were to pedagogy, a situation that nursing leaders came to recognise as a potential challenge to the status and professional aspirations of paid graduate nurses. ${ }^{70}$ Ironically, therefore, those teachers who eagerly opted for VAD service to demonstrate their patriotic sympathies also unwittingly entered into the potential debasement of women's acquired specialized occupational skills. Determined to be actively involved in the war effort, the VADs temporarily exchanged career and academic achievement to undertake a unique opportunity for patriotic service that was popularly recognised as suitable war work for women. Regardless of the subsequent lack of public recognition, the VADs nevertheless derived immense personal satisfaction from their war service, having "borrowed” the identity of military nurses to briefly experience the active war service otherwise denied to women

69 Sir Percy Sherwood, "President's Address," in Annual Report of the Canadian Branch of the St. John Ambulance Association, No. 16 (Ottawa 1925), 9.

70 See Quiney, “Assistant Angels,” 274-93. 
civilians. Half a century later, Agnes Wilson, the reluctant school teacher from Edmonton, still relished her time as a VAD, declaring: “Oh it was a marvellous experience! Really! I wouldn't have missed that for anything." 